\title{
EDITORIAL
}

\section{Literatura e outros conhecimentos}

Caro leitor, eis o título que atribuímos à nossa décima edição. De pronto, o assunto parece trazer o frescor da crônica, conversa de ontem ainda, em que a prosa literária se mete a confabular com outros saberes, sobretudo nesses nossos dias marcados não só por ideias que pululam e saltam de galho em galho, entabulando novas conversas, mas também por certa estranheza ao cânone, égide por vezes não absorvida por completo dada a sua originalidade ou porque sequer entendemos suas idiossincrasias (BLOOM, 2010, p. 15).

Mas, acredite, a literatura fala de tudo um pouco e seu papaguear é híbrido, mestiço, de modo que se torna difícil demarcar a origem dessa vizinhança, que se perdeu na poeira dos tempos. Tome-se, por exemplo, a Poética, de Aristóteles, até hoje considerada a Bíblia dos estudos literários ocidentais. Pois bem, em determinado entrecho, Aristóteles (2011, p. 54) tasca um de seus mais célebres mandamentos, distinguindo o poeta do historiador. Isto posto, pode-se inferir que as adjacências do literário remonta às premissas da própria literatura.

Pode-se também refletir sobre a elasticidade da escrita literária, sempre aberta aos diferentes saberes, razão pela qual, apontada como vulgarizadora do pensamento filosófico-científico, ainda hoje é vista por uns poucos com certo desdém. O mundo da literatura, notadamente após o advento da morte do autor, em que Barthes (1984, p. 66) cunha o termo scriptor assegurando ao leitor status de persona suscetível de amalgamar ao texto menções anteriores, exteriores e ulteriores ao texto (BARTHES, 1970, pp. 10-15), interpretando, ou melhor, apreciando-o de maneira plural, tal como ele é, tornou-se um universo sem limites para o diálogo com os mais diversos campos da sociologia, a antropologia, a etnologia, a filosofia e todas as 'ias' que o conhecimento abarca. 


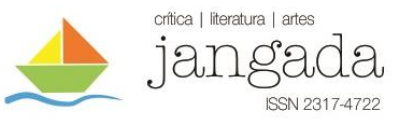

Ademais, conforme afirma Eco (2016, p. 14), “o mundo da literatura é um universo no qual é possível fazer testes para estabelecer se um leitor tem senso de realidade ou é vítima de suas alucinações". Ora, poder-se-ia perguntar, em que medida alucinamo-nos frente ao texto literário a ponto de fazê-lo abraçar diferentes discursos de modo a torná-lo não só interdidático, mas sobretudo interdisciplinar.

Mas o fato é que as personagens migram e trazem consigo não só suas desesperanças e decepções, mas, principalmente suas expectativas e esperanças e, ao fazê-lo, induzem o leitor a fazer afirmações verdadeiras sobre elas, simplesmente porque estão ali, eternizadas no texto literário. A leitura, como ato de recepção, explode as narrativas, inicia diálogos e faz o texto literário multiplicar-se em diferentes outros textos, cujas tipologias variam do filosóficocientífico àqueles plurais e representativos de áreas como as artes, a antropologia, a sociologia, a história etc, transformando-os em uma partituras musicais. Cabe ao leitor, materializar seu 'arranjo'.

Não por outra razão, afirma-se que a literatura é uma forma superior de conhecimento. Ao imitar a vida, recria a realidade, representa acontecimentos e fatos e é caminho aberto a novos modos de ler e interpretar o mundo. Por isso, o texto literário é multidisciplinar, aberto à metáfora e à potência metamórfica da criação; de índole antropofágica, estabelece incessante interação e absorve conhecimentos vários, da música às artes plásticas, do cinema à pintura, fazendo-se dialógico por natureza.

Neste número, os diálogos são férteis: o primeiro deles, "A relação da literatura de cordel na antroponímia dos fantoches populares portugueses", convida o leitor a mergulhar no mundo da arte teatral, mais especificamente o teatro de marionetes português; nele o autor desvela não só sua evolução, mas também certo desinteresse da classe teatral pelos fantoches, além de ressaltar a escassez de documentos, o que dificulta rastrear o percurso dessa arte ancestral. Na sequência, temos o artigo "Machado de Assis: a crônica e a seleção da notícia", em que o autor examina o fazer das crônicas pelo Bruxo do Cosme Velho a partir da seleção das notícias e dos embates do cronista frente à diagramação da página e também a restrição de espaço.

“O conceito 'museu é o mundo' de Hélio Oiticica no projeto 'Pimp my carroça' do grafiteiro Mundano" convida o leitor a ausentar-se da página e caminhar por espaços abertos, cruzar ruas e apreciar as carroças coloridas pelo artista Mundano. "Sou do mundo, sou Minas Gerais: o ser da experiência em 'Para Lennon e McCartney', discorre sobre como "a condição simultânea

$$
\text { Jangada | nr. 10, jul/dez, } 2017 \text { | ISSN 2317-4722 - } 2 \text { | Pá g i n a }
$$




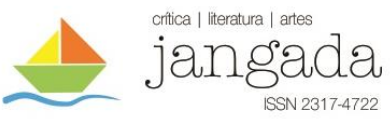

rural e urbana que compõe o espaço da periferia permite que o sujeito da experiência persista na modernidade"; a reflexão dá-se a partir da canção composta por Lô Borges, Márcio Borges e Fernando Brant, e eternizada na voz de Milton Nascimento.

"Precariedade, solidão e desintegração em $O$ Mundo Inimigo, de Luiz Ruffato", nos convida a descobrir o mundo do trabalho na ficção a partir da trajetória da personagem Zé Pinto, temática relacionada à desintegração e à solidão, relacionadas à forma romanesca. Em "O conceito de redução estrutural na crítica de Antonio Candido", tem-se a análise de três ensaios do grande crítico brasileiro, e, a partir deles, o autor discorre sobre a compreensão das estruturas das obras referenciadas nos tais ensaios. Por sua vez, "A arte contemporânea e a falta de interesse" nos traz uma reflexão sobre a complexidade da arte contemporânea, característica que, segundo o autor, induz o observador à confusão e, em alguns casos, afasta-o de seu circuito, gerando certo desinteresse. Fechando o bloco dos artigos, temos "Perspectivas de Leitura em sentido conotativo no conto 'A Menina de lá', de João Guimarães Rosa" repensa a prática da leitura como instrumento de compreensão e interpretação do texto literário. E, por fim, encerramos com ficção, o conto "Um quadro nenhum".

Dadas essa diferentes conversas e seus movimentos pendulares em diálogo com outros conhecimentos, desejamos ao leitor não só uma boa leitura, mas principalmente uma boa prosa!

Dirceu Magri Gracia Regina Gonçalves Editores deste número

\section{BIBLIOGRAFIA}

ARISTÓTELES. Poética. Tradução de Ana Maria Valente. $4^{\mathrm{a}}$ ed. Lisboa: Fundação Calouste Gulbenkian, 2011.

BARTHES, Roland. Le Bruissement de la langue. Paris: Éditions du Seuil, 1984. . S/Z. Paris: Éditions du Seuil, 1970.

BLOOM, Harold. O Cânone ocidental. Tradução de Marcos Santarrita. Rio de Janeiro: Objetiva, 2010.

ECO, Humberto. Sulla Letteratura. Milano: Bompiani; RCS Libri S.p.A, 2016. 